\title{
MOBbing: VIOLENCE AT WORK OR SEMANTIC ABUSE - THE EVALUATION OF THE PHENOMENON BY PROFESSIONALLY ACTIVE NURSES
}

\author{
Małgorzata Pasek ${ }^{1 A, B, C, D, E, F}$, Joanna Skrzeczyńska ${ }^{2 A, B, C, F}$, Grażyna Dębska2C,F, Helena Kaducakova ${ }^{3 C, E, F}$, \\ Lilia Suchocka ${ }^{4 C, D, E, F}$, Anna Goździalska ${ }^{2 A, C, D, E, F}$
}

\author{
'Department of Nursing, University of Applied Sciences in Tarnow, Poland \\ 2Faculty of Medicine and Health Sciences, Andrzej Frycz Modrzewski Krakow University, Poland \\ ${ }^{3}$ Department of Nursing, Catholic University in Ružomberok, Slovak Republic \\ ${ }^{4}$ Department of Psychology, The Jan Kochanowski University in Kielce, Poland \\ Authors' contribution: \\ A. Study design/planning • B. Data collection/entry $\bullet$ C. Data analysis/statistics $\bullet$ D. Data \\ interpretation $\bullet$ E. Preparation of manuscript $\bullet$ F. Literature analysis/search $\bullet$ G. Funds collection
}

\author{
Address for correspondence: \\ Dr Małgorzata Pasek \\ Department of Nursing \\ University of Applied Sciences \\ 8 Mickiewicza St., 33-100 Tarnów, Poland \\ e-mail:m_pasek@pwsztar.edu.pl \\ SUBMITTED: 1.06 .2020 \\ ACCEPTED: 8.07.2020 \\ DOI: https://doi.org/10.5114/ppiel.2020.98768
}

\begin{abstract}
Aim of the study: To assess the frequency of occurrence of mobbing in the work environment of professionally active nurses.

Material and methods: In order to collect data, the diagnostic survey method was deployed. The research instruments were a questionnaire designed by the author of this paper and a standardised questionnaire: Negative Acts Questionnaire (NAQ). Data for the study were collected from a sample of 150 professional nurses. Most of the respondents worked as a staff nurse.

Results: The assessed work environments were generally favourable in the group of respondents. On the other hand, the approaches to employees were perceived as mostly negative. The majority of the nurses participating in the research reported facing mobbing behaviour in the workplace. The majority of manifestations of mobbing that were experienced by the subjects in the last six months were creating rumours about the subjects, ignoring their views and opinions, and excessive control of their work.

Conclusions: It is advisable to introduce wide research on mobbing based on a standardised survey method. It can help in a wider analysis and comparison of the mobbing aspects at workplaces. The results obtained could be used to develop recovery programs in health care.
\end{abstract}

Key words: nurse, mobbing, NAQ questionnaire, violence at work, aggression in work.

\section{INTRODUCTION}

Aggression and violence at work has been a subject of interest for researchers throughout the world since the 1980s. In Poland, the issue of mobbing has only been taken up in recent years [1]. The main problems that arise when analysing the issue concern the difficulties in deciding which activities and behaviours qualify as mobbing, and which do not [2]. Because of different definitions of mobbing, there are inconsistencies in the results obtained by researchers. For this reason, research needs to be carried out, especially in Poland, using standardised research tools that allow for objective analysis of this phenomenon.

In the literature, we can find common features in the definitions of mobbing; they may be classified into three groups: those connected with the influence of the environment on internal organisational processes, those connected with the person carry- ing out the mobbing and the victim of mobbing, as well as those connected with the processes inside the organisation [3]. These features include irrational reasoning and lack of justification, a subjective perception, which can be intersubjectively validated, a manipulative character, internal differentiation, or a multidimensional and complex character. This indicates that mobbing is a phenomenon that takes many forms, which can cause problems for the research process [4].

The scale of mobbing has been increasing in recent years - this may be related to a real increase in the problem or to an increase in social awareness of people's rights. The number of complaints submitted to the Chief Inspectorate of Labour in Poland is growing [5]. Mobbing brings about numerous adverse effects both for the employee's personal development and career, and for the functioning of the organisation. This is the reason why article 94 of the Labour 
Code $\S 1$ obliges the employer to take action against mobbing. It is the employer who should introduce anti-mobbing policies, train the employees, and monitor the phenomenon [6].

Furthermore, in the last few years, the phenomenon of mobbing as a 'specific' type of conflict has been considered as an occupational risk factor directly linked to the functioning of the social environment. Hierarchical organisations, such as hospitals, are places where exposure to violent behaviour is greater than elsewhere. In the face of the changing structure of the labour market, the nurses' work is performed under increasing pressure, which intensifies the problem. Data from the Nofer Institute in Łódź provides evidence that, compared to other occupational groups, nurses are more exposed to violent behaviour in the workplace [7]. This may result from the specific nature of the nursing profession, characterised by the fact that in spite of high professional qualifications and very good occupational training, nurses struggle with a lack of a feeling of autonomy and with a lack of appreciation. This may be connected with limitations imposed on them in relation to decision-making, while at the same time the demands and expectations placed on them by their superiors, patients, and co-workers increase [7].

It is also worth citing the definition of mobbing as understood by the Polish Labour Code. According to art. $94^{3} \S 2$, workplace bullying includes acts or behaviours concerning an employee or directed against an employee, consisting of persistent and long-term harassment or intimidation of that employee, resulting in reduced self-esteem with respect to his/her professional abilities, or which is aimed at or results in the humiliation or ridicule of the employee, or the isolation or elimination of the employee from the group of co-workers [6]. To qualify an act as workplace bullying, three conditions need to be fulfilled simultaneously: 1) actions or behaviours directed against an employee, involving harassment or intimidation, 2) these actions have to be persistent and prolonged, and 3) the purpose of the actions must be to cause reduced professional self-esteem, or the humiliation or ridicule of the employee, or his/her isolation or elimination from his/her group of co-workers [8]. With regard to the perpetrator of the bullying, workplace bullying can be divided into three types: vertical from below, when a subordinate is the bully and a superior is the victim; horizontal (among peers), when the victim is bullied by co-workers; and vertical from above, when the victim is bullied by a superior [9].

In most cases, an employee bullied by a superior belongs to one of the following two opposing groups. The first group are employees with low qualifications and low self-esteem. These are people with low assertiveness, who are not able to stand up to their superiors and are aware of their low value on the labour market, which makes them feel trapped and completely helpless. The other group includes highly educated, ambitious, and creative people. They pose a threat to their superiors, who fear losing their position and therefore take action to undermine the subordinate's qualifications. The more capable an employee, the more prone she/he is to different forms of bullying [10].

The effects of mobbing are complex and multidimensional in nature, depending on the duration and intensity of the mobbing, as well as on the individual's capacity to cope. Generally speaking, these effects can be divided into those concerning the individual (victims and their families), effects on organisations (enterprises, institutions), and social impact. From a different perspective, the effects of bullying can be listed as follows: an emotional reaction (including fear, anger, helplessness), interpersonal difficulties (relationships with other people worsen), physical health problems (mainly headaches, stomach aches, insomnia), as well as changes in the victim's attitude to work (lower effectiveness) [11].

\section{AIM OF THE STUDY}

The aim of this work was to assess the frequency of occurrence of mobbing in the work environment of professionally active nurses and to show its causes, as well as to identify preventive actions that can be taken.

\section{MATERIAL AND METHODS}

To achieve the aim of this work, a diagnostic survey method was employed, using self-report questionnaires. Research tools included a self-report questionnaire developed by the authors of this paper and a standardised Negative Acts Questionnaire (NAQ) a Polish version adapted by Magdalena WarszewskaMakuch, who gave consent for its use in this work. This tool is used to measure the phenomenon of mobbing at the organisational level. It allows researchers to identify and assess the level of exposure to bullying in the workplace and to compare the indicators from different countries, occupational groups, etc. [12].

The procedures used were consistent with the current wording of the Helsinki Declaration. The survey was conducted on an anonymous and voluntary basis, and the participants were informed about this before they took the decision to fill out the questionnaires.

The results obtained were subjected to statistical analysis. All variables were either nominal or ordinal. Descriptive statistics were carried out using frequency tables and contingency tables [13]. The results were presented in numerical form $(n)$ and as percentages of responses (\%). Percentage values were calculated in relation to the number of answers, not of respondents, because it was not a requirement to answer 
Table 1. Sociodemographic characteristics of the study group

\begin{tabular}{lcc}
\hline Variable & $\begin{array}{c}\text { Examined } \\
(n)\end{array}$ & $\begin{array}{c}\text { Examined } \\
(\%)\end{array}$ \\
\hline Sex & 139 & 99 \\
\hline Women & 1 & 1 \\
\hline Men & & \\
\hline Age & 15 & 11 \\
\hline Up to 24 years old & 31 & 22 \\
\hline $25-29$ years old & 22 & 16 \\
\hline $30-34$ years old & 11 & 8 \\
\hline $35-39$ years old & 18 & 13 \\
\hline $40-44$ years old & 25 & 18 \\
\hline $45-49$ years old & 12 & 9 \\
\hline $50-54$ years old & 3 & 2 \\
\hline $55-59$ years old & 3 & 2 \\
\hline $60-64$ years old & & \\
\hline Marital status & 42 & 30 \\
\hline Single & 82 & 59 \\
\hline Married & 14 & 10 \\
\hline Divorced & 1 & 1 \\
\hline Widow & & \\
\hline & & \\
\hline
\end{tabular}

Table 2. Characteristics of the professional situation of the respondents

\begin{tabular}{|c|c|c|}
\hline Variable & $\begin{array}{l}\text { Examined } \\
(n)\end{array}$ & $\begin{array}{l}\text { Examined } \\
(\%)\end{array}$ \\
\hline \multicolumn{3}{|l|}{ Undergraduate education } \\
\hline Medical high school & 9 & 6 \\
\hline Medical studies & 4 & 3 \\
\hline Bachelor & 79 & 57 \\
\hline Masters & 47 & 34 \\
\hline \multicolumn{3}{|l|}{ Postgraduate education } \\
\hline Postgraduate education & 137 & 94 \\
\hline Divorced & 9 & 6 \\
\hline \multicolumn{3}{|l|}{ Professional experience } \\
\hline $1-5$ years & 51 & 37 \\
\hline 6-10 years & 17 & 12 \\
\hline $11-20$ years & 31 & 22 \\
\hline Over 20 years & 40 & 29 \\
\hline \multicolumn{3}{|l|}{ Workplace } \\
\hline Hospital ward & 120 & 91 \\
\hline Clinic & 7 & 5 \\
\hline Care and treatment institution & 2 & 1 \\
\hline Private medical facility & 1 & 1 \\
\hline Medical laboratory & 1 & 1 \\
\hline Sanatorium & 1 & 1 \\
\hline \multicolumn{3}{|l|}{ Workplace } \\
\hline Nurse in the ward & 123 & 89 \\
\hline Coordinating nurse & 9 & 7 \\
\hline Ward nurse & 6 & 4 \\
\hline
\end{tabular}

every question. Then, single factor analysis was used to determine the significance of the differences obtained. The $\chi^{2}$ independence test was used when two nominal or ordinal variables were compared. To test the significance of the dependence between nominal and ordinal variables, Kruskal-Wallis non-parametric analysis of variance was used. The level of significance adopted was $p<0.05$. Calculations were performed using STATISTICA software (StatSoft, 13.0).

The study group consisted of 150 individuals working as nurses. The respondents differed in age, marital status, length of service, position, education, and place of work. These variables were used to separate the nurses into the groups that were later used in the analysis. The socio-demographic and occupational characteristics of the surveyed group are shown in Tables 1 and 2.

Almost the whole study group consisted of women, in most cases married, aged 25-34 and 45-49 years. Ninety-four per cent of the respondents had completed higher education and had taken part in various forms of post-graduate training. The participants were mainly people with length of service from 1 to 5 years and more than 20 years, working in hospital departments (91\%), as staff nurses (89\%).

\section{RESULTS}

The study showed that $53 \%$ of respondents had encountered workplace bullying in the last six months.

Mobbing is a phenomenon that occurs in a significant number of healthcare institutions.

Personal experiences of mobbing in the workplace (assessed using our own self-report questionnaire) were declared by $73 \%$ of respondents. A significant proportion of them (33\%) experienced mobbing for a period longer than a year, more than $13.5 \%$ of respondents - from half a year to one year, more than $14 \%$ for $1-3$ months, and $12 \%$ of respondents - for a period shorter than a month.

Forty-three per cent of the respondents declared that they rarely observed bulling in their workplace, whereas $8 \%$ of them did not encounter the phenomenon in their workplace. Thirty-five per cent of the survey participants often encountered bulling at work, and $14 \%$ of them very often. Ninety-two per cent of the respondents observed mobbing occurring with various frequencies in their workplace.

In the study using the NAQ questionnaire, it was determined with the objective method that $57 \%$ of the study participants had been victims of mobbing (according to the Leymann's criterion of at least one negative act), and using the more rigorous criterion (at least two negative acts for questions 1-22 and question 23, answering "every now and then", "several times per week" or "almost every day") $28 \%$ of the respondents had been victims of mobbing. 
The subjective method of evaluation revealed that a significant proportion of respondents (47\%) stated that they were not bullied in their workplace. The rest of the respondents (53\%) admitted that they were victims of mobbing and that they were exposed to this phenomenon with various frequencies: "rarely" - $21 \%$ of respondents, "every now and then" $-21 \%$, "several times a week" $-6 \%$, and "almost every day" $-5 \%$.

Workplace bullying is, therefore, a common phenomenon in healthcare institutions - it concerns the employees personally, or it is witnessed or noticed by them. The results obtained concerning the prevalence of the phenomenon differ depending on the research tool applied.

In many workplaces there is an unpleasant atmosphere, and employees cannot always count on mutual respect.

A significant proportion of the respondents assessed the atmosphere in their workplace as "friendly" (36\% of respondents) or neutral (35\% of respondents), but very few assessed it as "very friendly" $-5 \%$ of respondents. At the other end of the scale, $3 \%$ of the respondents perceived their workplace as hostile, and $20 \%$ as unfriendly. The majority of the respondents described the atmosphere in their workplace as positive; however, a significant percentage described it as troubling - $23 \%$ in total assessed it negatively.

The way that employees are treated was assessed negatively by the majority of respondents: according to $48 \%$ of them, some employees received preferential treatment, more than $23 \%$ of the respondents noticed that some were treated worse than others, and $18 \%$ of the respondents stated that every employee was treated differently. Only $12 \%$ of the respondents declared that in their opinion everybody was treated equally.

The main manifestations of bullying are as follows: psychological aggression, lack of mutual respect, forcing the employee to carry out duties not included in their job description, and unwarranted criticism.

The most frequent forms of bullying witnessed by the respondents were: disregarding the opinions, suggestions, and ideas of the employee $(56 \%$ of the respondents); undermining their authority, ridiculing the employee in front of the team (59\%); and not involving the employee in decision making ( $43 \%$ of the respondent), threats, and intimidation (33\% of the respondents).

The forms of bulling most frequently experienced by the respondents personally were: disregarding the opinions, suggestions and ideas of the employee (35\%); undermining their authority, ridiculing the employee in front of the team (34\%); not involving the employee in decision making (22\%), threats, and in timidation (22\%). 29\% respondents did not encounter bullying personally. In the previous six months, the re- spondents had encountered manifestations of workplace bullying (Table 3).

Workplace bullying is closely related to such factors as age, length of service, position held, and the source of the bullying. The phenomenon more often affects young nurses and takes various forms, depending on their position in the organisation. The marital status of the respondent does not affect workplace bullying.

The age of respondents and their length of service were analysed and represented as ordinal variables. Frequency of bullying varied with age $(p=0.007)$ and was evaluated using the $\chi^{2}$ test. It was most often reported by nurses at the beginning of their careers, aged 25 to 35 years, as well as by those with a shorter

Table 3. Characteristics of the professional situation of the respondents

\begin{tabular}{|c|c|}
\hline $\begin{array}{l}\text { Manifestations of workplace bullying } \\
\text { in the previous six months }\end{array}$ & $\begin{array}{l}\text { Examined } \\
(\%)\end{array}$ \\
\hline $\begin{array}{l}\text { Spreading of rumours and gossip about the } \\
\text { respondents }\end{array}$ & 78 \\
\hline Excessive monitoring of work & 64 \\
\hline Assigning tasks below their level of qualification & 62 \\
\hline $\begin{array}{l}\text { Overloading with work that is impossible } \\
\text { for the respondents to perform }\end{array}$ & 61 \\
\hline Ignoring, excluding, or boycotting & 60 \\
\hline $\begin{array}{l}\text { Concealing information that affects the } \\
\text { respondents' work results }\end{array}$ & 60 \\
\hline Ignoring or hostility & 60 \\
\hline $\begin{array}{l}\text { Pressure not to demand something to which } \\
\text { they were entitled, e.g. sick leave, leave } \\
\text { of absence, refund of travel expenses }\end{array}$ & 55 \\
\hline
\end{tabular}

Repeatedly blaming respondents for mistakes $\quad 55$ made

\begin{tabular}{ll}
\hline Unjustified accusations & 56 \\
\hline Intimidation in the form of finger pointing, & 54
\end{tabular}
violation of personal space, pushing, or blocking the way

\begin{tabular}{lc}
\hline Constant criticism of someone's work and efforts & 54 \\
\hline Behaviours such as yelling, showing anger, rage & 54 \\
\hline $\begin{array}{l}\text { Taking credit for performing important tasks, } \\
\text { or allocating very simple or unpleasant } \\
\text { assignments instead of meaningful ones }\end{array}$ & 53 \\
\hline Regular mockery and sarcastic comments & 50 \\
\hline $\begin{array}{l}\text { Humiliating and ridiculing the respondents } \\
\text { about their work }\end{array}$ & 50 \\
\hline $\begin{array}{l}\text { Insulting or offensive remarks about individuals } \\
\text { (i.e. their habits, origin, views, private life) }\end{array}$ & 45 \\
\hline $\begin{array}{l}\text { Hints or signals that someone should quit work } \\
\text { The assignment of tasks the aims or deadlines } \\
\text { of which are unreasonable or impossible to fulfil }\end{array}$ & 32.9 \\
\hline “Jokes" from people with whom the respondents & 16.4 \\
did not have good relationships & 3 \\
\hline $\begin{array}{l}\text { Threats of physical force, or actual physical } \\
\text { harassment in workplace }\end{array}$ & \\
\hline
\end{tabular}


length of service ( $<10$ years); $p=0.005$. Meaningful differences were also noted in the sources of the mobbing. The younger nurses most often indicated their co-workers as the source, whereas older nurses indicated their superiors. A similar dependence was observed between the source of the mobbing and length of professional service $(p=0.02)$.

Some of the manifestations of mobbing that were experienced personally also seemed dependent on age. Chi-squared analysis with the use of contingency tables showed that the younger nurses more often reported that their opinions and views had been ignored $(p=0.009)$, they had been assigned tasks below their level of qualification ( $p=0.007)$, and pressure had been put on them not to demand something they were entitled to $(p=0.002)$.

Position held was analysed as a nominal variable. Staff nurses assessed the workplace atmosphere as significantly worse, compared to ward managers and coordinators. This was revealed by Kruskal-Wallis analysis $(p=0.048)$. Significant differences in the assessment of the way employees were treated depending on their positions $(p=0.03)$ were observed and described using the $\chi^{2}$ test. Ward managers in general indicated that employees were treated equally, while staff nurses and coordinators more often reported some employees receiving preferential treatment. It has not been shown, however, that any of the manifestations of mobbing experienced personally differed in frequency depending on position held.

Marital status was analysed as a nominal variable. Kruskal-Wallis analysis did not show any significant differences in the perception of the atmosphere in the workplace $(p=0.7)$ or the frequency of mobbing $(p=0.51)$ in relation to marital status.

Only threats and intimidation were reported significantly more often from a superior than from a coworker $(p<0.001)$. In the case of other manifestations of workplace bullying, there were no observable differences in their frequency in relation to the source of the bullying. This was determined with the chisquared test.

It is rare for action to be taken against mobbing; in most cases, manifestations of mobbing meet with no response, and those actions which are taken depend on age, position, and the source of the mobbing. Knowledge about anti-mobbing procedures differs, depending on length of service and position.

The majority of the people surveyed who had encountered mobbing in their workplace declared that they had made efforts to combat the phenomenon ( $43 \%$ of the respondents).

In reaction to bullying directed at another employee, the majority of the respondents responded or would respond with verbal comments ( $48 \%$ of respondents), conversation with the victim of the bullying (over $25 \%$ ), or by informing their superior (over
$16 \%)$. More than $4 \%$ of the respondents would not react in any way.

In most cases, the subjects who experienced bullying looked for help from their family and/or friends (37\% of respondents). They very rarely turned for help to trade unions, anti-mobbing associations, the police, or courts.

According to the respondents, the most common reasons why the victims of bullying did not inform the proper authorities about the occurrences of bulling were a lack of conviction that the help would be effective, and fear of retaliation by the perpetrator.

Nurses with longer length of service (> 10 years) more often declared a readiness to inform a superior about bullying in the workplace. This was shown by $\chi^{2}$ analysis $(p=0.02)$. However, a relationship between the frequency of actual action taken against the bullying experienced and the age of the nurses $(p=0.2)$ or their length of service $(p=0.66)$ has not been found.

Married or divorced nurses declared a readiness to talk directly to the perpetrator or to their superior significantly more often compared to those who had never married $(p=0.02)$. They also more often reported that they had already experienced bullying and had actively taken action against it $(p=0.03)$, as determined using the $\chi^{2}$ test.

There were no observed differences in declared reactions to bullying behaviours in relation to the position held ( $p=0.88$ )

The source of workplace bullying was analysed as a nominal variable. No statistically significant differences were noticed in action being taken against bullying, irrespective of whether the perpetrator was a co-worker or a superior ( $\chi^{2}$ analysis, $p=0.38$ ).

Older nurses more often indicated a knowledge of anti-mobbing procedures, whereas younger ones often did not know if these procedures existed in their workplace $(p=0.004)$. Ward managers and coordinators were significantly better informed about the existence of or the lack of anti-mobbing procedures, compared to staff nurses ( $\chi^{2}$ analysis, $p=0.008$ ).

The most common reasons for workplace bullying are lack of clearly defined rules at work, inappropriate division of responsibilities, and lack of managerial aptitude and interpersonal skills among managerial staff.

The main reasons for bullying in the nurses' occupational environment, as indicated by the respondents, included the following: inadequate staffing of managerial and decision-making positions, incompetence of superiors/managers, a lack of clearly defined rules and principles of work, and poor salary and bonus system.

According to the respondents, the main characteristics of the workplace that foster the occurrence of bullying behaviour included: unresolved and growing conflicts, inadequate organisational structure, un- 
clearly defined employee responsibilities of the employer, salaries inadequate for the work performed, and job losses.

\section{DISCUSSION}

The healthcare sector is considered an area in which significant numbers of emotionally abusive incidents are evident [14]. This may be due to specific organisational problems in hospitals and problems faced by the whole health care system. Hospitals are crowded places and working conditions are stressful, employees' salaries remain low, and professional expectations and demands are constantly increasing.

The phenomenon of workplace bullying refers to situations in which a single group repeatedly harasses, causes discomfort, and socially excludes another person [15]. Mobbing in the healthcare sector according to some authors most often takes the form of "horizontal" or "lateral" abuse towards nurses who have the same status [16]. This is a common phenomenon in the healthcare sector where the organisational culture remains hierarchical [14]. The results of a study conducted by Buchan et al. in 2005 indicate that nurses as a professional group experience mobbing three times more often than other people employed in the healthcare sector [17]. This indicates the importance of the problem and the need to undertake research in this area and to take remedial action.

In our study, $92 \%$ of respondents had witnessed mobbing at their workplace with various frequencies. On the other hand, $73 \%$ of respondents reported personal experience of being a victim of mobbing (our own questionnaire and question 23 of the NAQ questionnaire). According to objective methods of measurement, the level of mobbing in the study group was as follows: $57 \%$ (NAQ questionnaire - Leyman Criterium) and $28 \%$ (the rigorous criterion). Kozłowska and Doboszyńska carried out an analysis of the available literature on the scale of the occurrence of mobbing in a group of professional nurses in different countries. According to this review covering the period 1999-2010, the percentage of nurses who had been exposed to mobbing in the previous 12 months was as follows: the United Kingdom - 44\% (according to Quine L.), Poland - 56\%, Turkey - $86 \%$, USA - $31 \%$, Australia - 50\%, and Norway - 20\% [8]. It can be seen from this that, when compared with other countries, Poland is located at the average level of the occurrence of mobbing amongst the nursing profession [18]. Similar analysis of the research by Kunecka, Kamińska et al. in 2007 identified the level of mobbing among 1261 Szczecin nurses at 18.6\% using a Polish version of the NAQ questionnaire and the Leymann criterion [4]. Kunecka in 2015 carried out another study with the same questionnaire among
178 nurses, and then the level of mobbing was 34.3\% (Leymann criterion). Discrepancies between the reported data for Poland may be a result of the use of different measuring techniques, hence the reason for conducting extensive research based on standardised tools. Thanks to this the results may be comparable. The work of Kunecka may indicate an increase in the threat of mobbing in the work of nurses or an increase in knowledge and public awareness of this problem.

In our study, the most common forms of mobbing witnessed by respondents were as follows: disregard for employee opinions, suggestions, and ideas (56\%); undermining of authority, and ridicule in the presence of co-workers (59\%); the bypassing of employees in decision-making (43\%), threats, and intimidation (33\%); the deliberate delegation of tasks beneath the employee's competence (24\%); and isolation of the employee from the team (21\%). Zdziebło et al. in their research conducted among nurses from the Świętokrzyskie region obtained similar results [13]. The authors indicate that the most common types of mobbing were: overloading with work (39.0\%), using loud reprimands and shouting $(37.8 \%)$, ridiculing in the presence of other people (37.8\%), isolating the victim by treating them as if they were "invisible" (34.2\%), spreading rumours and false information (32.9\%), issuing threats especially threatening with job loss (30.5\%), allocating tasks beneath their capabilities (19.5\%), using offensive language (14.5\%), and using physical violence - striking and pushing (1.2\%) [1]. In our research, similarly to the results obtained by Zdziebło et al., threats to use or actual use of physical violence in the workplace affected a small percentage of respondents (our research $-3 \%$ ); however, the scale and importance of physical aggression appearing in the workplace remains disturbing [13].

Kunecka and Kamińska in their 2007 study analysed whether there were relationships between variables such as "whether someone was a victim of mobbing" according to an objective criterion and "whether someone was a victim of mobbing" according to a subjective criterion, and their declared employment, length of service, age, sex, education, and marital status. The authors showed a relationship between mobbing (using the objective method) and the age and education of the respondents. Persons with university education reported mobbing significantly more frequently than those with secondary or postsecondary education. On the other hand, people over the age of 42 years were significantly less likely to be victims of mobbing than those who were younger [4].

In our own research, similar results were obtained as to the existence of statistically significant differences in the frequency of observed mobbing, depending on the age of the subjects $(p=0.007)$. Mobbing was most often reported by nurses at the beginning of their careers (aged 25 to 35 years), and also by those 
with shorter length of service ( $<10$ years) $(p=0.005)$. In addition, younger nurses, more often than those in other age groups, reported their opinions and views being ignored $(p=0.009)$, being given work below their level of qualification ( $p=0.007)$, and being pressured not to demand something to which they were entitled ( $p=0.002)$. In our study, no significant differences were found in the perception of the atmosphere at work $(p=0.7)$ and the frequency of mobbing $(p=0.51)$, in relation to marital status.

Data from the literature review differ from those obtained in our own research regarding the sources of the mobbing. In our study, younger nurses most often referred to their co-workers as perpetrators, whereas older nurses said that it was their superiors. The results of studies by other authors carried out in Poland show that the source of the bullying was usually the victim's superior [15]. Similar data were obtained by Cevik Akyil, Tan et al., who analysed the sources of mobbing among Turkish nurses. In their study group over $58 \%$ of the people declared that it was their manager who was the most frequent perpetrator of violence against them [19].

Roche et al. identified workplace conditions that might foster the occurrence of mobbing behaviour. These included a staffing level of nursing staff that was too low, a heavy workload, unexpected changes in the needs of the people in their care, limits on the professional autonomy of nurses, and problems in dealings with doctors. In addition, the researchers found that the emergence of mobbing is related to the circumstances in which the work is being carried out, and it does not depend on the patient and the specifics of his/her illness and needs [20].

The main causes of mobbing in the professional environment of nurses mentioned in our own study were inadequate filling of managerial and decisionmaking posts, incompetence of superiors/managers, lack of clearly defined rules and principles of work, and poor salary and bonus systems. On the other hand, the most frequently mentioned features of a workplace fostering the occurrence of mobbing, according to the respondents, were unresolved and growing conflicts, inadequate organisational structure, unclearly defined employee job descriptions, salaries inadequate for the work performed, and job reductions. It is possible, therefore, to conclude that mobbing behaviour is caused by factors directly related to working conditions, as confirmed by the research of other authors [10].

Legislation imposes an obligation on the employer to counteract bullying in the workplace by creating anti-harassment procedures as well as disseminating information and monitoring the phenomenon in the workplace. However, individual preventative measures are listed in the literature that have a significant impact on the incidence and reduction of bullying in the workplace. According to the Chief Inspectorate of Labour, an important element is the employees' reaction to any unacceptable behaviour, both experienced personally and witnessed. On the first sign of harassment, co-workers, superiors, and people outside work should be informed. Silence is a kind of consent for the actions of the perpetrator, and when the victims broach the topic openly, it enables them to obtain the support they need. The Chief Inspectorate of Labour points out that the active response of witnesses of the abuse is also essential to counteract workplace bullying. Any witness should react by drawing attention to the perpetrator, talking to the victim, and informing the supervisor and other colleagues. Negative mobbing behaviour should become obvious and unacceptable to the group [21].

In our research, we collected data on how to respond to mobbing, how to seek support, and whether anti-mobbing procedures were in place in the workplace. Most respondents claimed to be attempting to combat workplace bullying (over 43\%). In response to mobbing directed towards another employee, $48 \%$ of respondents reacted or would react with a verbal comment, $25.7 \%$ by having a conversation with the victim, and over $16.7 \%$ by informing their superior. However, the percentage of people who say that they take action in response to mobbing seems to be too low compared to the scale of the problem. In most cases, the subjects who experienced bullying looked for help among their family and/or friends (37\% of respondents). It is a disturbing fact that as many as $21 \%$ of the respondents had not sought any help; a small percentage declared that they had sought help from their trade union, from their superior, or had talked to the perpetrator themselves, or to a psychologist from an anti-mobbing organisation. The most common reasons why victims of mobbing had refrained from reporting the incident to the relevant authorities were lack of faith in the effectiveness of any help and fear of retaliation by the perpetrator. In addition, nurses with greater length of service (> 10 years) more often indicated their readiness to notify their supervisor about mobbing at work. Nurses who were married or divorced were significantly more likely to talk directly to the person who was bullying or to his/ her supervisor, in comparison to those who had never been married $(p=0.02)$. They also reported more often that they had already experienced mobbing and had actively resisted it $(p=0.03)$. Older nurses more often indicated the presence of anti-mobbing procedures, while younger nurses often did not know whether such procedures existed in their workplace $(p=0.004)$. Ward managers and coordinators were better informed about the existence or absence of anti-mobbing procedures compared to staff nurses.

The results obtained allow us to conclude that the respondents do not have enough awareness of their 
ability to influence an abusive situation in the workplace. Despite increasing public awareness of the phenomenon of mobbing, it should continue to be the subject of research and of efforts to eliminate it.

\section{CONCLUSIONS}

Most respondents assessed the atmosphere at their work positively; however, the treatment of employees in the workplace was mostly assessed negatively.

Mobbing as a phenomenon was present among the nurses surveyed. The most common forms witnessed by the respondents were as follows: disregarding of the employees' opinions, suggestions, and ideas; undermining of their authority; ridiculing them in the presence of the team; leaving them out of decision-making; threats; and intimidation. The forms of mobbing that the respondents encountered personally were as follows: questioning of their authority; ridiculing in the presence of the team; disregarding their opinions, suggestions, and ideas; and missing them out of the decision-making process.

The phenomenon of workplace bullying is more commonly experienced by younger nurses with a shorter length of service ( $<10$ years). The younger nurses most often pointed to their co-workers as perpetrators of mobbing, while the older ones pointed to their superiors.

Most of the people surveyed who had encountered workplace bullying said that they had made attempts to combat the phenomenon, but a small percentage of the respondents, as compared to the scale of the problem, reacted or would react with a verbal comment, by talking to the victim of the mobbing, or by informing their supervisor.

The reasons for the occurrence of mobbing in the workplace that were most frequently indicated by the respondents were as follows: inadequate staffing of managerial and decision-making positions, incompetence of superiors/managers, a lack of clearly defined rules and principles of work, poor salary and bonus systems, unresolved and growing conflicts, inadequate organisational structure, unclearly defined employee responsibilities, salaries inadequate for the work performed, and job losses.

The most frequently indicated source of support against perceived bullying at work was family and friends.

\section{Disclosure}

The authors declare no conflict of interest.

\section{References}

1. Nerka A. Mobbing jako przykład nieetycznych zachowań w miejscu pracy. Annales. Etyka w życiu gospodarczym 2013; 16: 293-296.
2. Kozłowska L, Doboszyńska A. Mobbing w grupie zawodowej pielęgniarek. Probl Pielęg 2012; 20: 524-528.

3. Görgülüa N, Derya Beydak K, Sensoy F, et al. The effects of mobbing (bullying) on health employes. Proc Soc Behav Sci 2014; 152: 503-509.

4. Ostrowska M. Mobbing - przyczyny, konsekwencje, aspekty prawne. Zesz Nauk Firma i Rynek 2014; 1: 101-109.

5. Ustawa z 26 czerwca 1974 r. Kodeks Pracy z późn. zm., Dz.U.2019.0.1040.

6. Sidor-Rządkowska M. Mobbing - zagrożenie dla firmy i pracowników. Zarządzanie Zasobami Ludzkimi 2003; 2: 78-79.

7. Kunecka D. Negatywne zachowania w miejscu pracy w odniesieniu do pielęgniarek na przykładzie wybranych szpitali klinicznych. Bezp Pr 2015; 7: 21-23.

8. Merecz D, Mościcka A, Drabek M. Mobbing w środowisku pracy. Charakterystyka zjawiska, jego konsekwencje, aspekty prawne i sposoby przeciwdziałania. Instytut Medycyny Pracy, tódź 2005.

9. Erenkfeit K, Dudzińska L, Indyk A. Mobbing w środowisku pracy - opis zjawiska oraz jego skutki. Med Środ 2011; 4: 87.

10. Ziółkowska K. Zjawisko mobbingu w zakładzie pracy. Studia Warmińskie 2015; 52: 227-240.

11. Buchan J, Kingma M, Lorenzo M. International migration of nurses: Trends and policy implications. International Council of Nurses, Geneva, Switzerland 2005; 1-40.

12. Kucharska A. Pracownik wobec mobbingu, Państwowa Inspekcja Pracy. Główny Inspektorat Pracy, Warszawa 2019; 1: $1-28$.

13. Zdziebło K, Kozłowska E. Mobbing w środowisku pracy pielęgniarek. Probl Piel 2010; 18: 212-219.

14. Rak A, Gaweł G, Kowal A. Syndrom wypalenia zawodowego u pielęgniarek. Sztuka Leczenia 2000; 2: 72.

15. Roche M, Diers D, Duffield C, et al. Violence toward nurses, the work environnment and patient outcomes. J Nurs Scholarsh 2010; 42: 13-22.

16. Bechowska-Gebhardt A, Stalewski T. Mobbing. Patologia zarządzania personelem. Wydawnictwo Difin, Warszawa 2004.

17. Cevik Akyil R, Tan M, Saritas S, et al. Levels of mobbing perception among nurses in Eastern Turkey. Int Nurs Rev 2012; 59: 402-408.

18. Kunecka D, Kamińska M, Karakiewicz B. Skala zjawiska mobbingu wśród pielęgniarek/pielęgniarzy zatrudnionych w szczecińskich szpitalach. Med Pr 2008; 59: 223-228.

19. Drabek M, Merecz D, Mościcka A. Skala narażenia na agresję w miejscu pracy pracowników służby zdrowia i sektora ustug. Med Pr 2007; 58: 299-306.

20. American Nurses Association Board of Directors: Professional Issues Panel on Incivility, Bullying and Workplace Violence 2015; 1-23.

21. Hodgins M, MacCurtain S, Mannix-McNamara P. Workplace bullying and incivility: a systematic review of interventions. Int J Workplace Health Manag 2014; 7: 54-72. 